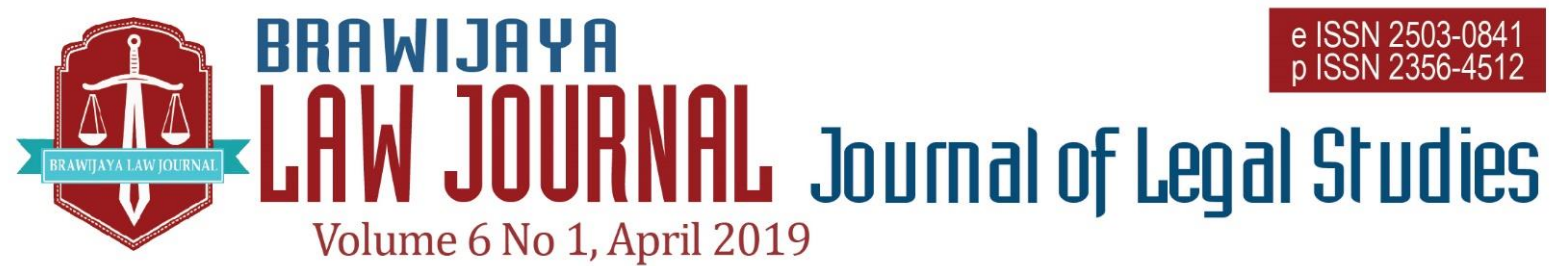

Nationally Accredited No. 30/E/KPT/2018 Dated 24th October 2018

This work is licensed under a Creative Commons Attribution-NonCommercial 4.0 International License

\title{
Arbitration and Other Alternative Dispute Resolution for Commercial Dispute (Reviewed from the Strengths of ADR and Decision of Arbitration)
}

\author{
Suherman $^{a}$ \\ ${ }^{a}$ Faculty of Law UPN Veteran Jakarta \\ Email : suherman_upn@gmail.com
}

Submitted : 2018-11-05 | Accepted : 2019-04-04

\begin{abstract}
Arbitration and other alternative dispute resolution (ADR) can be used as an option for parties who conduct commercial transactions. This research is crucial to analyse what is the best dispute method for parties to be able to resolve their commercial business disputes. It is argued that the most important of ADR is the efficiency and effectivines in relation to the enforcement of a judgement on the commercial dispute especially foreign arbitral award.

This research also seeks to analyse strengths and weaknesses of each ADR method because it is very important to know in resolving disputes in the field of trade and also related to the implementation of decisions, especially in foreign arbitral award and how to improve decisions and applied in Indonesia in relation to commercial dispute. The research method used in this research is normative juridical consisting of primary, secondary and tertiary legal materials, which were collected by conducting a literature review and interview technique and then processed qualitatively according to the problems and the theoretical framework logically and systematically to achieve the objective of this research, namely finding the best alternative dispute resolution in commercial dispute resolution in business transactions.

This paper argued that while each of ADR method has their own strengths and weaknesses, business actors mostly prefer too have arbitration method as their ADR method in solving their disputes. However, the applying mechanism of foreign arbitration awards need further attention from Indonesian government.
\end{abstract}

Keywords: alternative dispute resolution; arbitration; enforcement of a judgement.

\section{INTRODUCTION}

Arbitration is one part of alternative dispute resolution (ADR), aside from negotiation, mediation, conciliation and litigation. The important thing about ADR in commercial dispute resolution is the efficiency and effectiveness of the ADR decision. This ADR decision is very important in executing, because if in a case that has been decided it should be easy to be executed. Therefore, it needs to be examined and examined properly whether a decision from ADR has been efficient and effective in implementing the decision. Do not let the verdict from the ADR not be implemented properly even though it has used a long time 
in the process and has incurred large costs, but cannot be executed.

To be able to know the eficiency and effectiveness of an ADR decision in the execution of especially the arbitration award, it is necessary to know the weaknesses and strengths of each ADR and the legal strength of the ADR decision especially for international arbitration in Indonesia.

Arbitration and alternative dispute resolution laws regulate foreign arbitral award, namely a decision handed down by an arbitration institution or individual arbitrator outside the jurisdiction of the Republic of Indonesia, or put forward by an arbitration institution or individual arbitrator which is considered an arbitration award international. ${ }^{1}$

In the New York Convention 1958 Article 1 paragraph 1 envisages the foreign arbitral award is "This Convention shall be made in the territory of a State other than the State where the award is sought, and arising out of differences between persons, whether physical or legal. "It should also apply to the awards not considered as domestic awards in the State where their recognition and enforcement are sought."2

Based on the above definition, the existence of an foreign arbitral award is based on the principle of the region and what law is used in examining and deciding in resolving the dispute.

The 1958 New York Convention Regarding the Recognition and Implementation of International Arbitration has been ratified by Indonesia with Presidential Decree Number 34 of 1981. With the issuance of Presidential Decree 34 of 1981 Indonesia is bound by a legal obligation, to recognize and carry out any

1 Act Number 30 Year 1999 on Arbitration and Alternative Dispute Resolution Article 1 (9).
International Arbitration award requested for recognition and implementation in Indonesia with the principle of reprosity or reciprocity. Then as a follow up to Presidential Decree 34 of 1981 the Supreme Court of the Republic of Indonesia issued Regulation No. 1 of 1990 concerning Procedures for the Implementation of Foreign Arbirase Decisions.

The method used in this study is the Normative Juridical method so that the data is secondary data. The research materials in the form of primary materials are the main legislation. Law Number 30 of 1999 concerning Arbitration and Alternative Settlement Resolutions and other relevant rules such as the 1958 New York Convention Concerning the Recognition and Implementation of International Arbitration Awards and secondary materials in the form of books and the results of research and materials in the form of writing contained on the internet. Likewise tertiary material in the form of a dictionary and encyclopedia. All of the materials studied were then analyzed and then written with descriptive analysis method and then conclusions and recommendations were drawn as answers to the problem.

According to as mention above, Thus, the purpose of this paper is compare arbitration and other ADR to examining the strengths and weaknesses of arbitration and other ADR and How to Improve Efficiency and Effectivines of foreign arbitral award in Indonesia in relation to commercial dispute

\section{LEGAL MATERIALS AND METHODS}

Legal materials, which were collected by conducting a literature review and interview technique and then processed

21958 New York Convention article 1 paragraph 1 
qualitatively according to the problems and the theoretical framework logically and systematically to achieve the objective of this research, namely finding the best alternative dispute resolution in commercial dispute resolution in business transactions.

Legal materials used in this research include, Presidential Decree 34 of 1981 on the Ratification of The 1958 New York Convention Regarding the Recognition and Implementation of International Arbitration, Supreme Court Regulation No. 1 of 1990 concerning Procedures for the Implementation of Foreign Arbirase Decisions

\section{RESULT AND DISCUSSION}

At present, many countries in the world use ADR in resolving their business disputes, for example: in the United States have led to the use of non-formal justice for legal dispute resolution or ADR. ADR is the use of various methods for resolving an alternative to litigation. Thus, ADR as dispute resolution involves a structured process with third party decisions which are imposed on the parties. $\mathrm{ADR}$ is very much in design such as negotiation, mediation, conciliation, and arbitration. Before answering the questions above, in this study we will explain in advance the meaning of each ADR.

Negotiation: The most familiar resolution method dispute, which has been used for a long period of time, is negotiation. Negotiation is a process of joint decision making in which the disputants discuss their contradictory interests. In this way, they are searching for a mutual agreement which most likely can satisfy their interests. Negotiation must be the first among equal dispute

3 Robert Maddux, Successful Negotiation, (London sweet and maxwell, 1988) 14.

4 A. Taylor, Toward a Comprehensive Theory of Mediation, (A Mediator's Handbook, 1993) 2. resolutions processes, standing firm as its own right, as well as being into traditional frames. Negotiations on individuals who communicate with one another are in order to arrange their affairs in commerce and everyday life, establishing areas of agreement and reconciling areas of disagreements. Negotiation has also been defined as "the process we use to satisfy our needs when someone else contrls what we want". 3

Mediation : According to Reikert, mediation ${ }^{4}$ is" a process by which the disputants, assisted by a mutually acceptable neutral person (or persons), systematically isolate dispute adoption, consider alternatives, andreach a consensual agreement that will accommodate their needs". By this definition, there are three parties together in the mediation process. Two of them are the disputants and the other is a neutral person. The neutral person (or persons) acts as a facilitator to assist the parties to find a mutual settlement which will satisfy the disputants" interests. The neutral person, however, will not act as a judge to impose a decision upon the parties.. ${ }^{5}$

Conciliation : According to Lord Wilberforce, he defines conciliation in the aspect of commercial dispute resolution as : " ..... the process which the parties to a dispute are helped by a neutral and independent third party, who may be either and official provided by the state or a pri vate person, to reach a mutually acceptable settlement." 6 The conciliation process, like mediation, parties will be assisted by the neutral and independent third party to bring them together and define a solution in order to achieve the satisfactory agreement. The

5 Laurance Boulle, Mediation Principles Process Practice (Sydney Butterworths, 1996) 1.

6 Murray, Rau and Sherman, Processes of Dispute Resolution (Foundation Press, 1989) 69.

106 | Suherman - Arbitration and Other Alternative Dispute Resolution for Commercial Dispute... 
third person role is trying to conciliate the parties rather than resort to litigation. However, the process of conciliating the parties can be done whether they have already used litigation or not."7

Arbitration: At the current time, the dispute resolution which receives the most confidence in solving a variety of conflicts, especially in commercial matters, should be arbitration. This is because arbitration has derived many characteristic of the court system which, in reality, people still rely upon. Arbitration is a method of dispute resolution involving one more neutral third parties who are usually agreed to by the disputing parties and whose decision is binding. ${ }^{8}$ Arbitration in English law may be defined as aprivate mechanism for the resolution of disputes which takes place in private pursuant to an agreement between two or more parties, under which parties agree to be bound by the decision to be given by the arbitrator according to law after a fair hearing, such decision being enforceable at law. ${ }^{9}$

\section{The Strengths and Weaknesses of arbitration and other ADR.}

For all types of ADR, each of them, sometime, can work independently without any further assistance from from other types. Nevertheless, in case of the best result, some of them might need some other types to facilitate the proceeding. This is because each type of ADR has strengths and weakness.

\section{a. Arbitration}

Ibid.

8 Henry Campbell Black, Black's Law Dictionary (The law Exchange, Ltd, 1991).

9 PMB. Rowland, Arbitration Law and Practice (Butterworths, 2nd ed 1990)
The less formal procedures of arbitration seem to be a clear advantage. The most important thing is the proceedings may be arranged by the parties. Consequently, the parties can design the procedures better suited to their needs, especially to the specific features of the disputes in their commercial contract. $^{10}$

Further advantages of arbitrators are place, language, and applicable law. The parties can agree to manage those issues to suit' their best interests. The disputants can choose arbitrators who have experience and knowledge of commercial contracts. They may choose the venue where they may feel comfortable. The language which will be used in the arbitral procedures is also chosen by the parties. And finally, "the parties can choose the law applicable to the commercial contract, and that choice will almost always be respected by the arbitrators". ${ }^{11}$

In some case, the arbitral award may need to work along with judicial proceedings. "Since, under many legal systems, an enforcement of arbitral award may be done only on a specific number of dispute, for example that the arbitrators lacked authority to decide the dispute, that a party could not present his case in the arbitral proceedings, that the rules applicable to the appointment of arbitrators or to the arbitral procedure were not complied with, or that the award was contrary to public policy." 12

Nevertheless, at this time, the arbitral award are widely accepted and enforced more easily than foreign judicial decisions. This is a result of international conventions that assist in the recognition and enforcement

10 Priyatna Abdurrasyid, Arbitrase dan Alternatif Penyelesaian Sengketa (Fikahati aneska, 2nd Ed, 2011).

11 Rubino Sammartano, International Arbitration Law, (Kluwer Law and Taxation Publishers, 1990) 273.

12 Ibid. 
of foreign arbitral awards. Moreover, it must be noted that only in extremely rare case which the arbitral award need to be set aside from the courts to enforce an award. "This is the advantage of arbitration and the best. possible testimony in favor of this procedure. According to the statistics of the International Chamber of Commerce, 87 percent of the awards rendered by the court of Arbitration are freely executed by the losing party." 13

The strengths of arbitration is to achieve fair and appropriate resolutions of disputes with efficiency and economy. Some of the most important characteristics of arbitration are $:^{14}$

1). The decision maker is selected by the parties

2). The proceedings and award are private

3). The process is less formal then litigation

4). Legal rules of procedure and evidance do not apply, and

5). The process can beunderstood without formal legal training.

The arbitration hearing is more cheaper than a courtroom trial, because there are several reasons :

First, Evidance in arbitration can be introduced more quickly and with less dispute. In arbitration, fower motions are filed challenging the admissibility of evidance because court rules of evidence do not apply. Second, Courtroom trials are often conducted only in the morning so that judge can deal with motions in the afternoon. Trials conducted this way last longer but usually are no cheaper than trials conducted this way last longer but usuaally are no cheaper than trials conducted on a full day basis. Third, judges are frequently interrupted by emergency matters that will take precedence over a trial. This problem normally has no counterpart in arbitration. Finally, in comparing bench trials to arbitration, the judge's decision may be delayed by the time it takes for the judge to be furnished with a written transcript. ${ }^{15}$

\section{b. Negotiation}

The parties usually use negotiation when the dispute has just arisen. They tend to negotiate about their contrast interests and attempt to settle their conflict through the proceeding, The negotiation processes can be managed very simply by the parties' own effort and, generally, without any necessary assistance from the third person. As a result, even though the disputants agree to, use other methods because they could not settle their dispute by means of negotiation, they can resume to negotiate at any time they wish. ${ }^{16}$

In the proceeding itself, negotiation can help the parties to save times and costs in which may be required by another ADR methods. Moreover, a mutual agreement which is reached through negotiation may maintain and avoid any damages over a business relationship between the parties.

However, a serious weakness of negotiation is in enforcement. Due to the proceeding has been done by the parties' effort, there may be no specific regulations or an organization to enforce the settlement. The parties may ignore an agreement even though they have it written down. Moreover, the parties can walk out from the process at any stage when they do not want to negotiate.

\footnotetext{
15 Ibid, 7.

16 Chen, Understanding Chinese Negotiation, (Australian Dispute Journal, 1993)

3 Quentin Loh Sze On Sc and Edwin Lee Peng Khoon, Confidentiality in Arbitration : How far Does it extand, (Academy Publishing, 2007) 63.
}

14 American Arbitration Association, Handbook on Arbitration Practice, (JurisNet,LLC, 2010) 15.

108 | Suherman - Arbitration and Other Alternative Dispute Resolution for Commercial Dispute... 
Thus, the disputants have to initiate other ADR methods which will facilitate them to resolve the conflict more effectively. As a result, two more further consequences will arise. Firstly, duration time of the conflict resolving will be extended. And secondly, the cost of problem solving will be increased. ${ }^{17}$

Hence, negotiation can help the parties to resolve their disputes by mean of simple and easy processes and, probably, without damaging the parties' relationship. But, the enforcement is an important powerlessness characteristic which impacts negotiation not to be a final resort for resolving the disputes.

\section{c. Mediation}

Mediation is a decision making process in which the parties are assisted by a third party, the mediator. As mediator attempts to improve the process of decision making and to assist the parties reach an outcome to which each of them can assent. ${ }^{18}$

Because the parties attempt to find a solution through the assistance of the third party, this would be a benefit for them. Because in a conflict situation, more often the parties are angry. They may not be able to communicate effectively and it makes the dispute situation getting down. As a result, they may look over the real interests which they really need and tend to battle the other opponent to be a winner rather than compromise. With this situation, the mediator will help them to define what their interests are. He may try to convince the parties to look at the pro's and con's if they cannot agree on the settlement, such as greater costs if their conflict goes further.

The mediation is a highly flexible dispute resolution process. It can be

17 Ibid.

18 Laurance Boulle, above $\mathrm{n} 7$.

19 Ibid, 35. conducted in a variety of physical settings, the procedure can be negotiated and adapted, additional participants can be involved for part of the mediation. The informality of mediation is closely linked to its flexibility.Here informality refers to the setting, style and tone of the mediation and the interpersonal behaviour and conduct of the participants. The informality and flexibility of mediation allows for extensive and direct participation in the process. Mediation is a highly accessible system of dispute resolution. ${ }^{19}$

However, uncertain enforcement of mediation settlement seems to be an important weakness. This is because mediation is appointed by an agreement of the parties. Like other kinds of ADR, one party may ignore to perform the settlement and the other party must use another method which has the power for enforcing an agreement.

\section{d. Conciliation}

Conciliation is an alternative choice for parties who do not accept to submit to jurisdiction, whether it is the jurisdiction of another state or of an arbitrage tribunal. It is a non competitive method but litigation is not. Additionally, the business relationship between the disputants are more likely to be preserved. Moreover, conciliation may even develop the relationship between the parties, "since the scope of conciliation and the ultimate agreement of the parties may go beyond the strict confines of the dispute that gave rise to conciliation." 20

An obvious disadvantage of conciliation is not too much different from negotiation or mediation. That is, if the parties fail to conciliate, the money and time

20 Fulton, Maxwell J : Commercial Alternative Dispute Resolution, (The Law Book Company Limited, Sydney, 1989) 27. 
spent on it might have been wasted. "However, the parties can receive benefits from conciliation at the same level of confidentiality as arbitration." 21

There are some factors used to determine the strengths and weaknesses of arbitration and other alternative dispute resolution. Those factors can be classified as follows: Cost, Times of procedures, Flexibility, including informal proceedings and participation, Principles or organizations to support the procedures.

\section{1) Cost}

The budget of dispute resolution has become a forbidding factor for the parties. People wish to have the procedures or methods which can help them save money as much as possible. For this reason, it is quite obvious that litigation can cost a large amount of money. There is an estimation that in one year time, more than $\$ 80$ million has been used for intercorperate litigation. That money has been spent to hire lawyers and for other relevant proceedings, both in the court and outside. Moreover, the longer the time of the procedure also costs much more cost. This is absolutely a problem for all the parties. Meanwhile, negotiation, mediation, conciliation and arbitration seem to be the methods which can reduce the cost. Furthermore, the disputants also can control the expenditure in the processes as well. This is because they can manage the resolution by themselves and do not need to follow fixed principles. The disputants can do it without the assistant from an outside person for negotiation or may need some help from a, third party, for, mediation, conciliation, or arbitration. However, the number of outside people can be limited to a small number or may be only one person in each method. Additionally, the parties can specify the duration of time in a range that they wish. Hence, the alternative dispute resolution outside the court seems to be the appropriate way. $^{22}$

\section{2) Duration of time.}

The time can be controlled by the parties in every method ADR, but cannot be available in litigation. For arbitration, speed is a significant advantage. The person(s) who acts as the arbitrator usually is an expert. Consequently, the expert would know the feature of the conflict and can decide on a straight question of fact. As a result, the conflict can be resolved very quickly.

For negotiation and mediation, time can be short or long. It depends on the participation of the parties. This is because there is no rule, to frame a performance of the disputants. If they can reach a settlement without any, obstacle, the process will be a short. In contrast, if the parties do not cooperate appropriately, such as walk out from the process, negotiation or mediation will be delayed and can be terminated finally. As a result, the parties have to use further methods to resolve the dispute. As alternative dispute resolution is a conciliation, time can be short or long depending on the parties. Because of the non binding nature of conciliation, the parities may ignore to perform the conciliation agreement. Therefore, the court process has to be resumed to impose a decision to enforce the conciliation agreement which results in further time. $^{23}$

23 Ibid, 78

\footnotetext{
21 Ibid.

22 Sarah Rudolph Cole, managerial Litigation? The Overlooked Problem of Party Autonomy in Dispute Resolutio, (Hastings L.J, 2000) 75.
} 
3) Flexibility of procedure.

The parties are avoid the court system because of non flexible procedures. As mentioned previously, the parties cannot abandon one stage to perform the next stage of the court rules. They have to follow each of the rules in order. In other words, the court system is more formal and lacks flexibility. Furthermore, the fact that the court has a large number of case loads dictates that each of them must be decided in order as well. The parties cannot work on their dispute at anytime they wish. This also results in delaying of time which impose further impact for businesses of the parties either.

In contrast Its mediation, negotiation, conciliation, and arbitration, flexibility is the most significant of the procedures, especially the last one. Arbitration processing has been done privately between the parties and arbitrators. The arbitrators are appointed specifically for that dispute. The parties can choose to have a arbitral process in the form of running by one organization or private procedure as ad hoc arbitration. The parties may design the processes and the power of arbitrator, as well as choosing the law which will be applied. Hence, varying of flexibility can be available more in arbitration. ${ }^{24}$

\section{4) Principles or organization to support the procedures}

There are some organizations and principles to support the procedures. Arbitration has a number of organizations, such as the International Chamber of Commerce (ICC), or the American Arbitration Association (AAA), to support its work. Moreover, the United Nation Commission on International Trade Law (UNCITRAL) has played an outstanding role

24 J. Murray, A Rau and E Sherman, Process of Dispute Resolution ; The Role of Lawyers, (Foundation Press, 1989). in administrating the international commercial arbitration work as well. Those institutions have received ratification and worldwide acceptance from many states, particularly the super power countries such as USA. ADR success in United States, According to the statistics provided by the Department of justice in 2017, over $\$ 15$ million was saved from litigation , 14000 days of attoeney and staff time saved, and almost 2000 months of litigation avoided. So, That is clear, ADR is more efficient and cost effective means to resolving disputes, thereby highlighting its significance. ${ }^{25}$

In Indonesia organizations that support the procedure with arbitration are the Indonesian National Arbitration Board (BANI), which is an independent institution that provides services to resolve disputes through arbitration. BANI was formed by the Indonesian Chamber of Commerce and Industry (KADIN) in 1977, with the aim of participating in law enforcement efforts in Indonesia to organize dispute resolution that occurred in various trade sectors.

\section{Improving Efficiency and Effectivines of Foreign Arbitral Award in Indonesia in Relation to Commercial Dispute}

The most important thing at the end of a dispute is the implementation of a decision on the dispute, meaning that the decision can be carried out properly by the parties or through court assistance to carry out the execution. There are several factors that will influence to increase efficiency and effectiveness of foreign arbitration decisions in Indonesia, namely :

\section{a. Foreign arbitration decisions are based on final and binding}

25 Malikul S. Muhamad, Alternative Dispute Resolution in India and the United states, (Cornell University, J .Purushotham \& Associates, 2010). 
In the 1958 New York Convention it was said that

"each contracting state shall recognize arbitral awards as binding and enforce them in accordance with the rules of procedure of the territory where the awards is relied upon, under the conditions laid down in the following articles. There shall not be imposed substantially more onerous conditions or higher fees or charges on the recognition or enforcement of arbitral awards to which this Convention applies than are imposed on the recognition or enforcement of domestic arbitral awards."

Based on this article, it means that each member country of the Convention must recognize an foreign arbitral award as a binding decision and has an execution against the parties. Meanwhile, in the arbitration law and alternative dispute resolution in Indonesia, the final and binding strength of an foreign arbitral award is illustrated in Article 68 paragraph 1 of the International Arbitration Law, namely: "Regarding the decision of the Chairperson of the Central Jakarta District Court as referred to in Article 66 letter d acknowledging and implementing an International Arbitration Award, cannot be appealed or appealed. "It is stated in this article that international arbitration that is recognized and implemented in Indonesia cannot be appealed or appealed, this is in accordance with the final and binding principle possessed by an international arbitration award. ${ }^{26}$

\section{b. Foreign arbitration decisions are based on reciprocity}

26 Arfiana Novera, Mera Utama, Fundamentals of Contract and Arbitration Law (Malang: Tunggal Mandiri, 2014) 112.
The principle of reciprocity is the recognition of the execution of foreign arbitral awards. This principle is reflected in Article 66 letter a of the Arbitration Law and Alternative Dispute Resolution which states: "foreign arbitral awards are imposed by arbitrators or arbitral tribunals in a country which with the Indonesian state are bound to an agreement, both bilaterally and multilaterally, regarding the recognition and implementation of Arbitration Awards International."

In the New Yok Convention in 1958 it was also stated that "any state may be on the basis of a reciprocity declare."

This principle must be considered by the court when it wants to give the executor's request. In Article 3 PERMA No. 1 of 1990 also states that arbitration decisions that are recognized and which can be executed in the jurisdiction of the Republic of Indonesia, are only decisions that fulfill the principle of reciprocity.

Article 3 of the New York Convention requires participating countries to recognize arbitral awards made abroad to have legal force and implement them in accordance with national law in which the decision will be implemented. However, the recognition and legal obligations cannot be separated from the principle of reciprocity or reciprocity between countries concerned with the participating countries of the convention. The willingness of the state to acknowledge and execute international arbitration awards must apply reciprocally with the recognition and willingness of other countries, to execute international arbitration awards. Recognition and implementation of foreign arbitral award $s$ must be based on bilateral or multilateral relations of the countries concerned in terms

112 | Suherman - Arbitration and Other Alternative Dispute Resolution for Commercial Dispute... 
of recognition and implementation of foreign arbitral awards.

\section{c. Ensure the efficiency of the execution of processes}

The process for the execution of international arbitration awards is in the court, so that the court is not authorized to question the material that is being dropped. The main duty of the court in carrying out its executor's function is only to examine whether the international arbitration award violates formal principles or rules that are serious and fundamental, namely that they must not violate public order. ${ }^{27}$

\section{d. Ensure Accountability of Court.}

Many people think that court decisions are unfair and not accountable because of the many court decisions that can be bought and sold. Moreover, the number of judges affected by corruption cases is related to buying and selling decisions. So that there needs to be an accountable court that all judges and other members under the court are free from corruption.

\section{e. Changing Mindset of the Court.}

Changing the mindset of all parties in the court in carrying out foreign arbitration decisions in Indonesia, because the legal force of foreign arbitral awards in Indonesia has been regulated in law, the government still must endeavor that the arbitral award made abroad must be respected and carried out. Awards and commitments to foreign arbitral awards in Indonesia are still very minimal, so it takes a lot of the role of the court as a controlling tool so that foreign arbitral awards can truly be carried out domestically.

27 Susilawetty, Arbitration and Alternative Dispute Resolution are reviewed in the Legislative

\section{CONCLUSIONS AND SUGGESTIONS}

Alternative dispute resolution is settlement disputes outside of the courtroom. ADR includes early neutral evaluation, negotiation, conciliation, mediation, and arbitration. Each type of ADR has strengths and weaknesses which can be seen from the cost, duration of flexibility, procedure, principles or organization to support procedures and the implementation of decisions of each type of ADR. When viewed from the above criteria, arbitration has the power of a decision to be requested for execution through a court. The difficulty in applying foreign arbitration award in Indonesia can be done through the principle of final and appeal, principle of reciprocity, Ensure Efficiency of the execution processes, Ensure Accountability of Court and Changing Mindset of the Court.

\section{REFERENCES}

\section{Books}

Abdurrasyid, Priyatna, Arbitrase dan Alternatif Penyelesaian Sengketa (Fikahati aneska, 2nd Ed, 2011).

American Arbitration Association, Handbook on Arbitration Practice, (JurisNet, LLC, 2010)

American Arbitration Association, HandBook on International Arbitration and ADR (JurisNett,LLC, 2nd edition, 2010)
A. Taylor, Toward a Comprehensive Theory of Mediation, (A Mediator's Handbook, 1993)

Perspective, (Jakarta: Gramata Publishing, 2013) 46. 
Black, Henry Campbell, Black's Law Dictionary, (The law Exchange, Ltd, 1991).

Boulle, Laurance, Mediation Principles Process Practice, (Sydney Butterworths, 1996).

Chen, Understanding Chinese Negotiation, (Australian Dispute Journal, 1993)

J Fulton, MaxwellCommercial Alternative Dispute Resolution, (The Law Book Company Limited, Sydney, 1989)

J. Murray, A Rau and E Sherman, Process of Dispute Resolution ; The Role of Lawyers, (Foundation Press, 1989)

Loh Sze On Sc, Quentin and Lee Peng Khoon, Edwin, Confidentiality in Arbitration : How far Does it extand, (Academy Publishing, 2007)

Maddux, Robert, Successful Negotiation, (London sweet and maxwell, 1988).

PMB. Rowland, Arbitration Law and Practice, (Butterworths, 2nd ed, 1990) Cole, Sarah Rudolph managerial Litigation? The Overlooked Problem of Party
Autonomy in Dispute Resolutio,

(Hastings L.J, 2000)

Sammartano, Rubino, International Arbitration Law, (Kluwer Law and Taxation Publishers, 1990)

Sherman, Rau and Murray, Processes of Dispute Resolution, (Foundation Press, 1989)

\section{Journals Articles}

Shavel, Steven, 'Alternative Dispute Resolution : An Economic Analysis', (1995) 24 (1, January) The Journal of Legal Studies

<www.journal.chicago.edu. >

\section{Legislations}

The 1958 New York Convention Regarding the Recognition and Implementation of International Arbitration

Supreme Court Regulation No. 1 of 1990 concerning Procedures for the Implementation of Foreign Arbirase Decisions

Presidential Decree 34 of 1981 